\title{
Structure and Spatial Distribution of Dead Wood in Two Temperate Old-Growth Mixed European Beech Forests
}

\author{
Diana VASILE ${ }^{1}$, Any Mary PETRITAN ${ }^{1}$, Nicu Constantin TUDOSE ${ }^{1}$, \\ Florin Lucian TOIU ${ }^{1}$, Virgil SCARLATESCU ${ }^{1}$, Ion Catalin PETRITAN ${ }^{2 *}$ \\ ${ }^{I}$ National Institute for Research and Development in Forestry "Marin Drăcea", Cloșca 13, 500040, Brașov, \\ Romania;diana_vasile@ymail.com; apetritan@gmail.com; cntudose@yahoo.com; florinluciantoiu@yahoo.com;virgils_ro@yahoo.com \\ ${ }^{2}$ Transilvania University of Braşov, Faculty of Silviculture and Forest Engineering, Sirul Beethoven 1, 500123, Brassov, \\ Romania;petritan@unitbv.ro ("correspondingauthor)
}

\begin{abstract}
Old-growth forests are often looked at as reference for close to nature silviculture, which aims to manage forests in a natural way. An important component of these forests is the large amount of deadwood they possess; the role of dead wood in the forest ecosystem has been well recognised. A detailed investigation of dead wood characteristics (the amount per stand, species, dead wood type, decay class, size and spatial distribution) was performed in two Romanian old-growth European mixed beech forests: Runcu Grosi Reserve (sessile oak-beech) and Sinca (silver fir-beech). Dead wood pieces were classified as belonging to one of seven dead wood types and one of five decay classes. The total amount of the dead wood was greater in Runcu Grosi $\left(240.8 \mathrm{~m}^{3} \mathrm{ha}^{-1}\right)$ than in Sinca Forest $\left(135.5 \mathrm{~m}^{3} \mathrm{ha}^{-1}\right)$. The majority of the dead wood in Runcu Grosi was composed of sessile oak (91.7\%), whereas in Sinca Forest, the main dead wood species was silver fir (67.0\%); both species exhibited higher values of probability density than beech, the second most important species. The dead wood exhibited much variation in tree size and in dead wood type, and covered the entire spectrum of decomposition classes. The main spatial pattern of all standing dead trees was random in both forests (over 55\%), with a reduced participation of regularity and aggregation. The results of this investigation could be used as key values derived from natural conditions to enhance the biodiversity related to dead wood in managed temperate beech mixed forests.
\end{abstract}

Keywords: Abies alba, Fagus sylvatica, Carpathian Mountains, random pattern, Quercus petraea, virgin forests

\section{Introduction}

Dead wood in its different forms (standing dead trees, fallen dead wood, stumps) is a major structural and functional component of forest ecosystems (Harmon et al., 1986). Dead wood contributes to the accumulation of organic matter in the soil, provides habitat for decomposer organisms, maintains moisture during dry periods, can be an important substrate for the regeneration of many tree species, and represents a capital pool of nutrients and carbon storage (Harmon et al., 1986; Harmon and Sexton, 1996; Wirth et al., 2002; Bolton and D'Amato, 2011). Furthermore, dead wood maintains biodiversity in forest ecosystems, as it provides habitat and shelter for bacteria, fungi, bryophytes, arthropods, birds and mammals (Stokland et al., 2012).

Natural tree mortality processes (senescence, selfthinning), canopy damage and natural pruning produce deadwood inputs in natural forests, whereas in managed forests, logging activities influence dead wood input rates. Additionally, the occasional occurrence of major natural disturbances (i.e. wind storms, insect attacks) can introduce further amounts of dead wood (Harmon et al., 2013).

Old-growth forests, where dead wood contributes approximately $20 \%$ of the total forest carbon stock (Harmon et al., 1990), are often characterised by larger quantities of deadwood that cover the entire spectrum of decomposition classes. Although old-growth forests may serve as a reference for managed forests, providing important information for conservation and promoting biodiversity, few studies have examined quantity and quality (dead wood types, decay classes), size class distribution and spatial patterns of dead trees in natural forests (Oheimb et al., 2007; Rahman et al., 2008; Amanzadeh et al., 2013), mainly due to the scarcity and inaccessibility of remnant virgin forests. In particular, this applies to remnant natural beech forests in Southeastern Europe. Despite the very large surface area of virgin forests still existing in the Carpathian Mountains, the important aspects of dead wood, such as 
640

quantity of different dead wood types or the spatial distribution of dead trees have been poorly explored.

In Romania, forests occupy an estimated 7,046,056 ha (IFN, The National Forest Inventory; http://roifn.ro/site/ rezultate-ifn-1/), and approximately 220,000 ha of this area consists of virgin forests (Veen et al., 2010). The paucity of data concerning dead wood in old-growth forests requires a specific and detailed investigation in old-growth forests of Romania. Because beech forests exist as pure stands or as mixed stands with other broadleaved species (e.g. oak species) or coniferous species (e.g. silver fir, Norway spruce), these are the most common natural forest types in Romania. In this study, we attempted to investigate the amount of dead wood present in two mixed beech dominated oldgrowth forests, categorised by dead wood types (according to Oheimb et al., 2007), diameter distribution and spatial patterns. The main aim was to comparatively analyse how the most important aspects related to dead wood (quantity, quality and spatial distribution) could be influenced by the admixture of species identity, specifically species existing in mixed beech dominated forests (i.e. sessile oak and silver fir, two species with different shade tolerance). Hence, our goal was to improve our knowledge concerning the description of the main aspects of dead wood, allowing us to prescribe suitable practical guidelines for forest management with the purpose of enhancing biodiversity in mixed beech forests.

\section{Materials and Methods}

\section{Study area}

The data for this study were collected from two different natural mixed forest types with European beech as main species in the tree canopy composition: a sessile oak-beech forest and a silver fir-beech forest. The investigated sessile oak-beech mixed
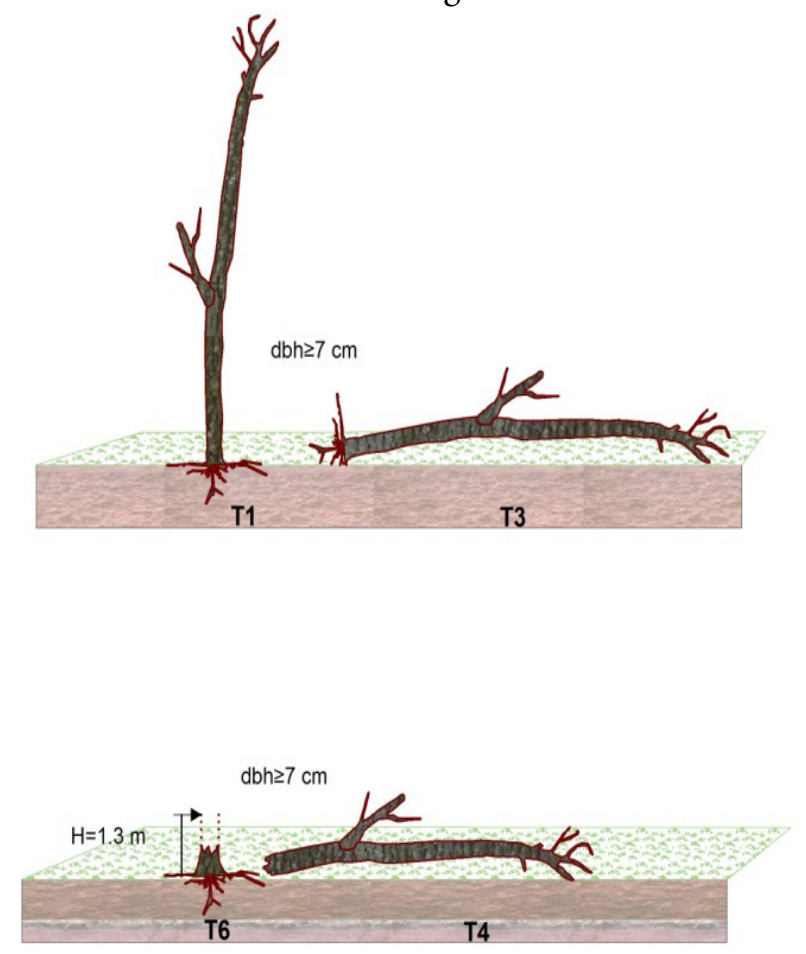

stand is located in the Runcu Grosi Natural Reserve (261.8 ha), western Romania $\left(46^{\circ} 11^{\prime} \mathrm{N}\right.$ and $\left.22^{\circ} 07^{\prime} \mathrm{E}\right)$ and is part of Nature 2000 Site ROSCI0070-Drocea. The climate that characterises this region is temperate continental, with a mean annual precipitation of approximately $687 \mathrm{~mm}$ and a mean annual temperature of $9.8^{\circ} \mathrm{C}$. Soils in the area are cambisols and luvisols, with a good water and nutrient supply. The bestpreserved part of this Reserve (32.3 ha, 22.1276 E 46.1722N), situated at an altitude between 440 and $680 \mathrm{~m}$ a.s.l., consists of old-growth mixed stands dominated by sessile oak (Petritan $e t$ al., 2013, 2014).

The second investigated mixed forest type is located in the virgin forest Sinca $\left(45^{\circ} 40^{\prime} \mathrm{N}\right.$ and $\left.25^{\circ} 10^{\prime} \mathrm{E}\right)$, near Brasov, Romania. The climate there is also temperate continental, but the mean annual temperature is much lower $\left(4.5^{\circ} \mathrm{C}\right)$ and the mean annual precipitation is higher $(1000 \mathrm{~mm})$ than that of Runcu Grosi. On a bedrock of crystalline schist, there are abundant cambisols, with a good water and nutrient supply. The forest is situated between 850 and $1350 \mathrm{~m}$ a.s.l., with slopes ranging from 30 to $40^{\circ}$.

\section{Fieldsampling}

A detailed investigation of the different dead wood types and decay stages was conducted on four 0.56 ha intensive sampling plots $(75 \times 75 \mathrm{~m})$ established in the best-preserved part of the Runcu Grosi Natural Reserve. Data concerning dead wood in the Sinca virgin forest were collected from 21 rectangular $(35 \times 35 \mathrm{~m})$ randomly-chosen plots spread over the entire area (Petritan et al., 2015).

At both sites, within each sample plot, the species, diameter at breast height $(\mathrm{dbh})$ and height were recorded for all living and dead trees with a dbh $\geq 7 \mathrm{~cm}$. Each piece of dead wood was identified by species and categorised as belonging to one of seven types of dead wood described in Oheimb et al. (2007).
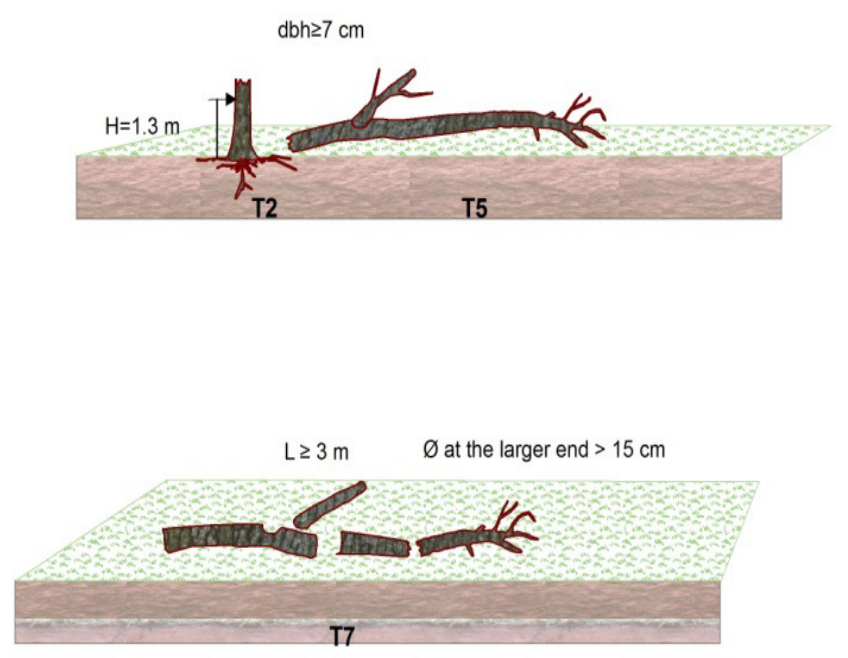

Fig. 1. Dead wood types according to Oheimb et al. (2007): (T1) whole standing dead tree, (T2) snags, (T3) uprooted tree, (T4) fallen dead tree, (T5) fallen snags, (T6) stumps and (T7) fallen trunk or branch fragments 
Three types of standing dead wood were defined: T1, a whole standing dead tree (with a dbh $\geq 7 \mathrm{~cm}$ ); T2, snags (snapped trees with a stump height $\geq 1.3 \mathrm{~m}, \mathrm{dbh} \geq 7 \mathrm{~cm}$ ); and T6, stumps (snapped tree with a stump height $<1.3 \mathrm{~m}$ ). For lying dead wood, four types were defined: $\mathrm{T} 3$, uprooted tree ( $\mathrm{dbh} \geq$ $7 \mathrm{~cm}$ ); T4, fallen dead tree (originated from a snapped tree or stump of height $<1.3 \mathrm{~m}$ ); T5, fallen snags (originated from a snapped tree or stump of height $\geq 1.3 \mathrm{~m}$ ); and T , fallen trunk or branch fragments (diameter at the thicker end $\geq 15 \mathrm{~cm}$ and length $\geq 3 \mathrm{~m}$ ) (Fig. 1).

For standing dead trees, the dbh and height were measured; in the case of stumps, the diameters at both ends were also measured. For all lying dead trees, the diameter at both ends and total length were recorded. Five decay classes were defined according to Keller (2011): fresh (DC 1), hard (DC 2), rotten (DC 3), mouldering (DC 4) or mull wood (DC 5). The angles between a sampled dead tree considered as a reference tree and its four nearest neighbours $\left(\alpha_{j}\right)$ were quickly assessed in the field as being greater or smaller than the standard angle value using $\left(360^{\circ} /(\mathrm{n}+1)\right.$, with $\mathrm{n}$ being the number of neighbours, according to Hui and Gadow (2002). Typically, this step took less than a minute.

\section{Data analysis}

The volume of the living trees and whole standing dead trees was calculated using a double-logarithmic regression equation (Giurgiu and Draghiciu, 2004), whereas the volume of lying dead wood types, stumps and snags was calculated using the formula of the truncated cone. The spatial structure of the sampled dead wood trees was characterised by the spatial distribution of the standing dead trees' positions (T1, T2 and T6) using the uniform angle index (Hui and Gadow, 2002; Aguirre et al., 2003). We used this method because it requires little effort during a normal field inventory, as it does not require tree coordinates to be known (it is not necessary to measure the distances between neighbouring trees and the reference tree).
The uniform angle index (W) describes the degree of regularity of the spatial distribution of the four nearest neighbours $j$ to a reference tree $i$ and it is defined as the proportion of angle $\left(\alpha_{i}\right)$ that is smaller than the standard angle $\alpha_{0}$, which is expected in a regular point distribution:

$$
W=\frac{1}{4} \sum_{j=1}^{4} w_{j} \text {, with } \mathrm{w}_{\mathrm{j}}=1 \text { if } \alpha_{\mathrm{j}}<\alpha_{0} \text {, otherwise } \mathrm{w}_{\mathrm{j}}=0 .
$$

Mortality probability density functions (probability computed for each diameter class as the conditional probability that a tree is dead in a given diameter class and simultaneously belonging to this diameter class) and diameter distributions of living trees and of standing dead trees (T1, T2) were fitted using a distance-weighted least squares smoothing technique (McLain, 1974), and the goodness of fit was examined using the likelihood-ratio $\chi^{2}$ test. All analyses were performed in Statistica 12.0 (StatSoft, Inc., 2013).

\section{Results}

\section{Dead wood amount}

The total amount of dead wood observed was greater in Runcu Grosi $\left(240.8 \mathrm{~m}^{3} \mathrm{ha}^{-1}\right)$ than in Sinca Forest $\left(135.5 \mathrm{~m}^{3}\right.$ $\mathrm{ha}^{-1}$; Table 1). In Runcu Grosi, the beech accounted for only $8.2 \%$ of the total dead wood volume, whereas in Sinca Forest, $31.8 \%$ of the total dead wood consisted of beech. The majority of dead wood in Runcu Grosi was sessile oak (91.7\%), whereas the main dead wood species in Sinca Forest was silver fir (67.0\%). The other species observed (Carpinus betulus, Quercus cerris, Acer pseudoplatanus, Prunus avium, Ulmus glabra, Tillia cordata and Sorbus torminalis) accounted for $<1 \%$ of the dead wood.

Most dead wood from sessile oak belonged to type T3 (uprooted tree, 51\%), followed by T1 (whole standing dead tree, 34\%). The distribution of the dead wood volume of silver fir was more balanced between the different types, with $27 \%$ of

Table 1. Mean volume $\left(\mathrm{m}^{3} \mathrm{ha}^{-1}\right)$ and range (min-max) of dead wood by species and type in two studied forests in Romania, Runcu Grosi Nature Reserve and Sinca Forest

\begin{tabular}{|c|c|c|c|c|c|c|c|c|}
\hline \multirow[b]{2}{*}{ Dead wood type } & \multicolumn{4}{|c|}{ Runcu Grosi } & \multicolumn{4}{|c|}{ Sinca } \\
\hline & Beech & $\begin{array}{c}\text { Sessile } \\
\text { oak }\end{array}$ & $\begin{array}{l}\text { Other } \\
\text { species }\end{array}$ & Total & Beech & $\begin{array}{l}\text { Silver } \\
\text { fir }\end{array}$ & $\begin{array}{l}\text { Other } \\
\text { species }\end{array}$ & Total \\
\hline $\begin{array}{l}\text { Standing entire dead trees } \\
\text { (T1) }\end{array}$ & $1.4(0.1-3.9)$ & $\begin{array}{c}74.5 \\
(38.6-136.4)\end{array}$ & $\begin{array}{c}0.2 \\
(0-0.9)\end{array}$ & $\begin{array}{c}76.1 \\
(39.1136 .4)\end{array}$ & $\begin{array}{c}6.8 \\
(0-56.4)\end{array}$ & $\begin{array}{c}21.9 \\
(0-127.4)\end{array}$ & 0 & $\begin{array}{c}28.7 \\
(0-127)\end{array}$ \\
\hline Snags (T2) & $\begin{array}{c}3.8 \\
(0-7.9)\end{array}$ & $\begin{array}{c}5.8 \\
(0.4-11.4)\end{array}$ & 0 & $\begin{array}{c}9.5 \\
(0.4-15.8)\end{array}$ & $\begin{array}{c}5.4 \\
(0-42.3)\end{array}$ & $\begin{array}{c}6.9 \\
(0-35.9)\end{array}$ & 0 & $\begin{array}{c}12.3 \\
(0-42.3)\end{array}$ \\
\hline Uprooted trees (T3) & $\begin{array}{c}1.9 \\
(0-3.7)\end{array}$ & $\begin{array}{c}111.6 \\
(95.5-145.3)\end{array}$ & 0 & $\begin{array}{c}113.5 \\
(97.2-147.6)\end{array}$ & $\begin{array}{c}8.2 \\
(0-48.2)\end{array}$ & $\begin{array}{c}10.3 \\
(0-96.5)\end{array}$ & $\begin{array}{c}0.1 \\
(0-1.31)\end{array}$ & $\begin{array}{c}18.5 \\
(0-96.5)\end{array}$ \\
\hline Fallen dead trees (T4) & $\begin{array}{c}4.2 \\
(0.1-14.5)\end{array}$ & $\begin{array}{c}4.0 \\
(0.9-7.1)\end{array}$ & 0 & $\begin{array}{c}8.2 \\
(2.0-15.3)\end{array}$ & $\begin{array}{c}7.4 \\
(0-80.6)\end{array}$ & $\begin{array}{c}15.5 \\
(0-92.1)\end{array}$ & 0 & $\begin{array}{c}22.9 \\
(0-92.1)\end{array}$ \\
\hline Fallen snags (T5) & $\begin{array}{c}1.0 \\
(0.3-2.6)\end{array}$ & $\begin{array}{c}6.6 \\
(1.3-10.8)\end{array}$ & 0 & $\begin{array}{c}7.6 \\
(1.0-10.9)\end{array}$ & $\begin{array}{c}5.9 \\
(0-35.4)\end{array}$ & $\begin{array}{c}11.2 \\
(0-64.7)\end{array}$ & 0 & $\begin{array}{c}17.1 \\
(0-64.7)\end{array}$ \\
\hline Stumps (T6) & $\begin{array}{c}0.5 \\
(0-2.0)\end{array}$ & $\begin{array}{c}4.8 \\
(0-5.4)\end{array}$ & 0 & $\begin{array}{c}5.3 \\
(0-4.5)\end{array}$ & $\begin{array}{c}0.1 \\
(0-1.6)\end{array}$ & $\begin{array}{c}0.3 \\
(0-3.19)\end{array}$ & 0 & $\begin{array}{c}0.4 \\
(0-3.2)\end{array}$ \\
\hline $\begin{array}{l}\text { Fallen trunk or branch } \\
\text { fragments (T7) }\end{array}$ & $\begin{array}{c}6.9 \\
(0.9-20.5)\end{array}$ & $\begin{array}{c}13.6 \\
(9.1-24.3)\end{array}$ & 0 & $\begin{array}{c}20.5 \\
(11.7-31.3)\end{array}$ & $\begin{array}{c}10.3 \\
(0-36.2)\end{array}$ & $\begin{array}{c}24.70 \\
(0-154.8)\end{array}$ & $\begin{array}{c}0.51 \\
(0-9.14)\end{array}$ & $\begin{array}{c}35.5 \\
(0-154.8)\end{array}$ \\
\hline Total dead wood & $\begin{array}{c}19.1 \\
(6.9-34.7)\end{array}$ & $\begin{array}{c}220.9 \\
(164.5-265.6)\end{array}$ & $\begin{array}{c}0.2 \\
(0-0.9)\end{array}$ & 240.8 & $\begin{array}{c}44.1 \\
(0-80.6)\end{array}$ & $\begin{array}{c}90.8 \\
(0-154.8)\end{array}$ & $\begin{array}{c}0.57 \\
(0-9.14)\end{array}$ & 135.5 \\
\hline
\end{tabular}


642
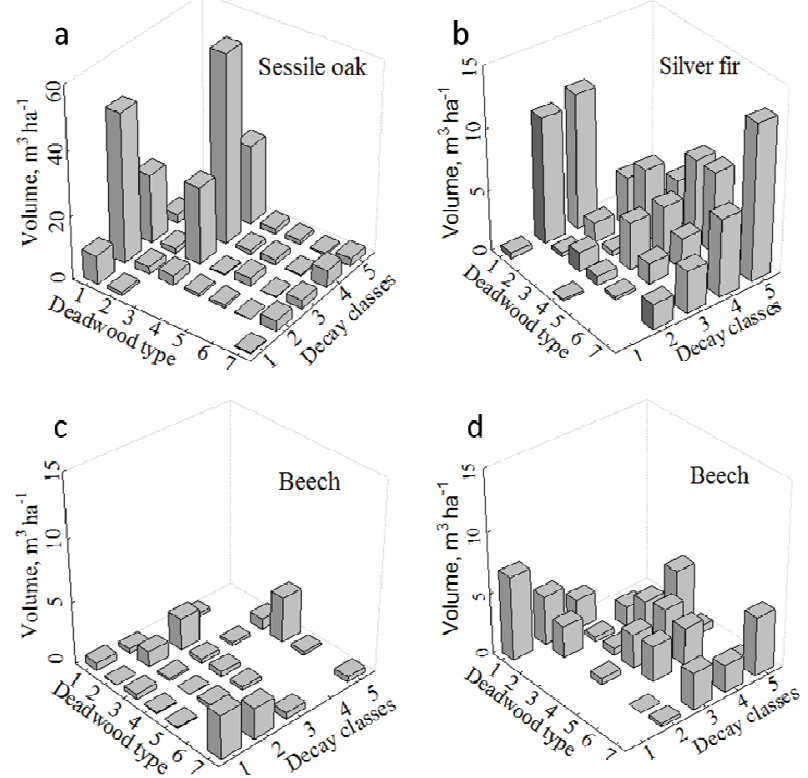

Fig. 2. Distribution of dead wood volume $\left(\mathrm{m}^{3} \mathrm{ha}^{-1}\right)$ by trees species, dead wood types and decay classes in Runcu Grosi (a, c) and Sinca Forest (b, d)

volume in the form of fallen trunks or branch fragments (T7), $24 \%$ as $\mathrm{T} 1$ and $37 \%$ as snapped trees with different broken heights ( $8 \%$ as snags and $29 \%$ as fallen trees; Table 1$)$. In contrast with sessile oak and silver fir, the percentage of whole standing dead beech was lower (only 7\% in Runcu Grosi and $15 \%$ in Sinca Forest). A large amount of beech dead wood was found in the form of fallen trunks or branch fragments - 35\% in Runcu Grosi and 23\% in Sinca. The majority of beech dead wood volume was made up of snapped (broken) trees with different snapping heights - either snapped at a height $>1.3 \mathrm{~m}$ (T2 and T5) or at a height $<1.3 \mathrm{~m}$ (T6 and T4; Table 1).

\section{Dead wood type and decay class distribution}

Dead wood from all decay classes was found at both investigated locations. Sessile oak dead wood showed varying distribution among decay classes, depending on the dead wood type. Most of the sessile oak dead wood belonging to the T1 type was in the second decay class (DC 2 - hard dead wood), whereas most dead wood of type T3 (uprooted trees) was in DC 4 (mouldering dead wood; Fig. 2a). Silver fir deadwood that existed as whole standing trees was typically in DC 2 and DC 3, while dead wood belonging to the other dead wood types was predominantly in the most decayed classes (DC 4 and DC 5; Fig. 2b). A similar pattern occurred for beech in Sinca Forest, with the exception of dead wood of type T1, which was mainly fresh (DC 2 and DC 3; Fig. 2d).

In both forests, standing dead trees (T1, T2 and T6) were mainly DC $2-61 \%$ of the total dead wood volume in Runcu Grosi and 43\% in Sinca - whereas fallen dead trees (T3, T4, and T5) were mainly in DC 4 in Runcu Grosi ( $45 \%$ of the total volume of dead wood) and in DC 5 in Sinca (43\% of the total volume of dead trees).

\section{Diameter distribution of standing dead trees}

In Runcu Grosi, a large proportion of beech in small diameter classes caused a negative exponential tendency of diameter distributions at the stand level (Fig. 3a,c), whereas the
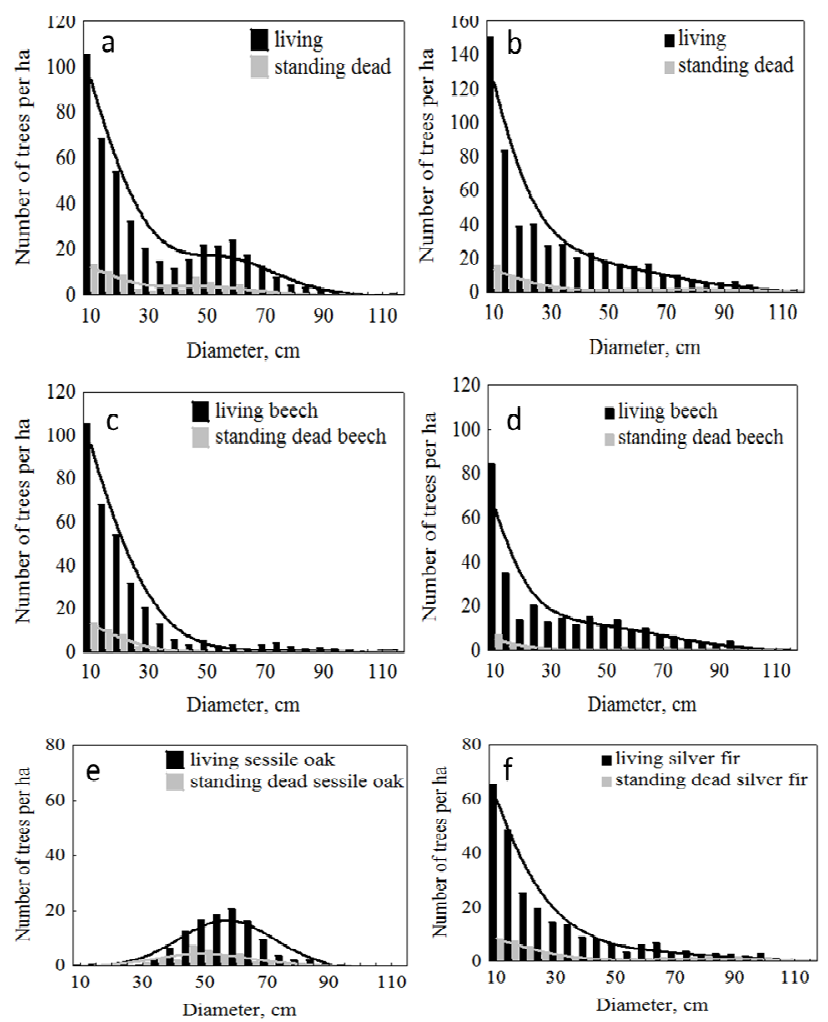

Fig. 3. Diameter distribution of living trees and standing dead trees ( $\mathrm{T} 1$ and $\mathrm{T} 2$ ) as mean number of trees $\mathrm{ha}^{-1}$ in Runcu Groşi (a, c, e) and in Sinca (b, d, f)
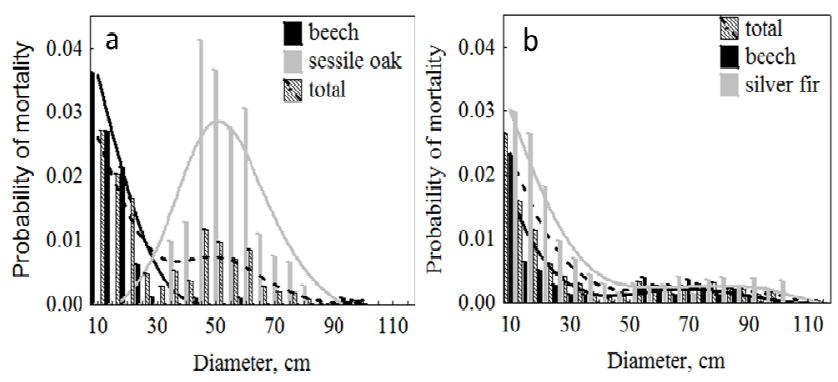

Fig. 4. Mortality probability density function of standing dead trees (T1 and T2) for Runcu Grosi (a) and Sinca Forest (b)
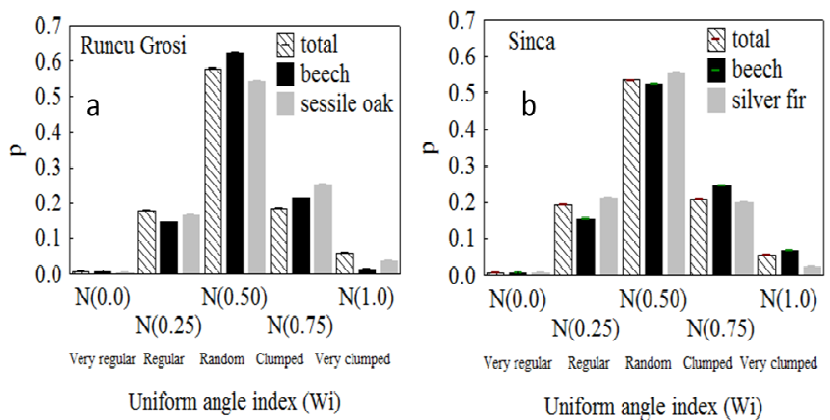

Fig. 5. Spatial standing dead trees distribution for Runcu Grosi (a) and for Sinca Forest (b) 
existence of a peak in the middle diameter classes was provoked by the normal pattern of sessile oak diameter distribution (Fig. 3e). Sessile oak formed this middle layer because of a reduced number of seedlings and saplings belonging to the small diameter classes, due to their lower shade tolerance. Consequently, the diameter distribution of standing dead trees followed a similar pattern to that of living trees.

In Sinca Forest, where shade-tolerant species such as beech and silver fir regenerate continuously very well and survive for long periods of time under limited light availability conditions, living and dead diameter distributions were more close to the negative exponential curve, with no peak of curves in the middle diameter classes (Fig. 3b, d, f). Distance-weighted least squares approximation offered a good curve fitting for all diameter distributions ( $p>0.05, \chi^{2}$ test).

Sessile oak in Runcu Grosi and silver fir in Sinca exhibited higher values for probability of mortality compared to beech, but with a distinguished pattern: whereas silver fir mortality occurred predominantly in the small diameter classes, similarly to beech (10-30 cm; Fig. 4b), sessile oak mortality occurred predominantly in the middle diameter classes, with a pronounced peak in diameter of $45-65 \mathrm{~cm}$, where the probability values were greater than $3 \%$ (Fig. $4 a$ ).

\section{Spatial distribution of dead trees}

The mean uniform angle (W) of the two species in each forest was similar $(0.48-0.53)$ and indicated a random distribution of dead wood trees, with more than $50 \%$ of all dead trees having a $\mathrm{Wi}=0.50$ (Fig. 5 ).

\section{Discussion}

Total amount and tree species composition are the most assessed characteristics of dead wood in different natural and near-natural beech-dominated forests of Central and SouthEastern Europe (e.g. Korpel', 1995; Tabaku, 2000; Vrška et al., 2001; Oheimb et al., 2007). In a review of data concerning dead wood quantity across beech forest reserves around Europe, Christensen et al. (2005) computed a mean value of dead wood volume of $130 \mathrm{~m}^{3} \mathrm{ha}^{-1}$ and mentioned a high variation among reserves, ranging from nearly nil to $550 \mathrm{~m}^{3}$ ha ${ }^{1}$. Although the mean value of dead wood in Sinca $\left(135 \mathrm{~m}^{3} \mathrm{ha}^{-1}\right)$ was very close to the mean found by Christensen et al. (2005), dead wood volume in Runcu Grosi forest was approximately $100 \mathrm{~m}^{3} \mathrm{ha}^{-1}$ greater than this European mean $\left(233 \mathrm{~m}^{3} \mathrm{ha}^{-1}\right)$. The dead to live wood ratio of sessile oak in Runcu Grosi (30\%) was higher than that of silver fir in Sinca (21\%), whereas the dead to live wood ratio of beech was similar for both forests $(6 \%$ vs. $7 \%$, respectively). At the stand level, the dead to live ratio was approximately $30 \%$ in Runcu Grosi, a value very close to the mean of long-established submontane/lowland reserves found by Christensen et al. (2005). In contrast, in Sinca the ratio averaged 15\% (Petritan et al., 2015), approximately half the value of long-established montane European beech reserves (36\%; Christensen et al., 2005).

In Sinca Forest, the greatest amount of dead wood was in the most advanced decay stages (DC 4 and DC 5) for both species and for all dead wood types, with the exception of whole standing dead wood, which had occurred more recently (DC 1-3). In Runcu Grosi, fallen pieces of beech trunks or large branches appeared to have died in the last decade (DC 1-2).
Although a considerable amount of whole standing dead sessile oak trees $\left(70 \mathrm{~m}^{3} \mathrm{ha}^{-1}\right)$ occurred over the last few decades (DC 2-3), approximately $90 \mathrm{~m}^{3} \mathrm{ha}^{-1}$ of sessile oak trees appeared as uprooted trees, but in advanced stages of decomposition (DC 3-5). Our results confirm previous findings that have reported this difference in the time necessary for sessile oak and beech to fall over. According to Peterken (2001) and Vandekerkhove et al. (2009), the majority of sessile oak dies standing and requires several decades before falling over, mainly due to slow decay rates and a very well-developed root system. In comparison, only 10 years are required for standing dead beech trees to fall over (Korpel', 1995; von Oheimb et al., 2007).

Usually, in old-growth forests, due to competition pressure for light, density-dependent mortality (self-thinning) is the dominant natural process in small diameter classes, and consequently the most commonly-occurring pattern of standing dead trees in these diameters is an inverse J-curve distribution. Although dead beech and silver fir trees exhibited a higher representation in the smaller diameters, a higher proportion of standing dead sessile oak trees with intermediate dimensions were normally distributed, hampering the negative exponential distribution with a shift towards a rotated sigmoid diameter pattern. Most standing dead sessile oak trees had diameters of $35-65 \mathrm{~cm}$, which exhibited the greatest value of probability of mortality (3\%).

The main spatial pattern of all dead trees was random in both forests $(\mathrm{W}=0.5)$, with a reduced participation of regularity $(\mathrm{W}=0.25)$ and of aggregation $(\mathrm{W}=0.75)$. The random pattern appeared mainly as a consequence of continuous single tree mortality caused by ageing among the large standing trees during the late developmental stage (Parish et al., 1999), whereas the spatially-aggregated pattern suggests an earlier growth stage, where light competition is high and competition is more important in defining a spatial pattern than age-related mortality (Rouvinen and Kouki, 2002). A small-scale or low-intensity disturbances regime (events such as the death of individual trees or groups of a few trees due to external abiotic and biotic factors) dominated both forests during the last decades and hence are likely to have determined a predominantly random pattern of dead trees (Petritan et al., 2013, 2015). Similar studies carried out in beech forests confirm our results. Oheimb et al. (2007) found the same pattern in a temperate near-natural beech forest in Germany; in an 8-ha sample plot, the overall spatial distribution of dead trees exhibited a random pattern, whereas uprooted beech trees deviated from random to an aggregated pattern. In unmanaged Caspian beech forests in Iran, Amanzadeh et al. (2013) observed a random spatial pattern of dead trees in two plots and detected significant spatial aggregation in only one plot, a plot governed by high density-dependent competition (selfthinning). Conversely, a significant aggregated pattern of standing and fallen dead trees was detected in Albanian virgin beech forests according to Meyer et al. (2003). Vacek et al. (2015) investigated the spatial pattern of dead wood trees in a natural Norway spruce-beech forest in the Czech Republic over 40 years. They found that fallen and standing dead spruce trees exhibited a constant random pattern over the whole observed period, whereas dead beech trees presented a shift from randomness towards aggregation over the last decade. Standing dead beech and Norway spruce trees, however, were randomly distributed. 
644

Beech revealed a more pronounced character of randomness in Runcu Grosi ( $p=63 \%)$ than in Sinca $(p=53 \%)$. This difference in probability between the two forests was not significant, however $(p>0.05$, comparison of two proportions, $\mathrm{u}$ test). In both forests, approximately $23 \%$ of dead beech trees were positioned in clumps (Wi=0.75), and ca. $16 \%$ of them were regularly distributed. The admixture species of beech formed a higher percentage of clumped parts $(\mathrm{Wi}=0.75)$ in Runcu Grosi (24\% for sessile oak) relative to Sinca Forest (19\% for silver fir). In contrast, the proportion of dead silver fir trees that formed regular patches in Sinca $(\mathrm{Wi}=0.25)$ was slightly higher than that of sessile oak in Runcu Grosi (21\% vs. $15 \%$, respectively). This suggests that sessile oak trees in admixture with beech are subjected to higher pressure compared to silver fir, mainly due to their different shade tolerance.

Since dead wood is an important component of forest ecosystems and enhances biodiversity through providing major habitats for insects, birds, reptiles, amphibians, small mammals, fungi, lichens and bryophytes (Harmon et al., 1986; Odor and Standovar, 2001; Siitonen, 2001; Heilmann-Clausen and Christensen, 2003), the level of naturalness of a forest may be described not only by the quantity of dead wood, but also by its quality (dead wood types, decay classes, size distribution) and spatial distribution pattern. A mean value of dead wood volume reported in European managed beech forests does not exceed $10 \mathrm{~m}^{3} \mathrm{ha}^{-1}$, and originated from stumps and logging waste (Meyer, 1999; Tabaku, 2000). A detailed analysis concerning the quantity and quality of dead wood needed in a managed forest, however, should take into account mainly tree species composition, the identity and level of biodiversity that must be maintained or increased (for whichever species of plants and animals the given forest should offer a good microhabitat in time and space - e.g. fungi and bryophytes exhibit the highest diversity on fallen trees in certain decomposition stages; Odor and Standovar, 2002; HeilmannClausen and Christensen, 2003), the different development stages occurring in the forest and the main functions attributed to a certain forest (e.g. reducing erosion, storing waters and nutrients). To increase the overall dead wood volume in managed forests, it is necessary to preserve some commercial timber in the forest and periodically to mark some trees to produce standing dead trees and snags. This marking should occur at shorter time intervals for beech and silver fir, which have similar decay rates according to Lombardi et al. (2008), than it should for sessile oak, which has lower decomposition rates (Vandekerkhove et al. 2009). Based on our results, the proportion of "man-made dead wood trees" should be more pronounced among admixtures of sessile oak or silver fir in comparison to only beech. Furthermore, the distribution of these artificial new standing dead trees should exhibit a random pattern, similar to the distribution found in our investigation.

\section{Conclusions}

The amount of dead wood distributed per species, type, decay class and size class found in the present study is a good indicator of the naturalness level of the investigated forests, and could be a very helpful tool with which forest managers could increase biodiversity and obtain other benefits (erosion mitigation, substrate for the regeneration of tree species, capital pool of nutrients and carbon storage) related to maintaining a greater amount of dead wood in managed temperate beech mixed forests.

\section{Acknowledgements}

This work was financed by the Romanian National Authority from Scientific Research and Innovation (ANCSI, project number PN 16330204). N.C. Tudose acknowledges financial support of The Executive Unit for the Financing Higher Education, Research, Development and Innovation (UEFISCDI) from project research title "Environmental friendly solutions in protected areas ROSCI0207 Postavaru, ROSCI0195 Piatra Mare and ROSCI0038 Ciucas" (acronym project SEAAT, grant number 96/2014). I.C. Petritan acknowledges financial support of a grant from the Romanian National Authority for Scientific Research and Innovation, CNCS - UEFISCDI, Project PN-II-RU-TE-2014-4-0791.

\section{References}

Aguirre O, Hui G, von Gadow K, Jiménez J (2003). An analysis of spatial forest structure using neighbourhood-based variables. Forest Ecology and Management 183:137-145.

Amanzadeh B, Sagheb-Taleb Kh, Foumani BS, Fadaie F, Camarero JJ, Linares JC (2013). Spatial distribution and volume of dead wood in unmanaged Caspian beech (Fagus orientalis) forests from northern Iran. Forests 4:751-765.

Bolton N, D'Amato AW (2011). Regeneration responses to gap size and coarse woody debris in forest harvests patterned after natural disturbances in northeastern Minnesota, USA. Forest Ecology and Management 262:1215-1222.

Christensen M, Hahn K, Mountford EP, Ódor P, Standovàr T, Rozenbergar D, ... Vrška T (2005). Dead wood in European beech (Fagus sylvatica) forest reserves. Forest Ecology and Management 210:267-282.

Giurgiu V, Draghiciu D (2004). Modele matematico-auxologice si tabele de productie pentru arborete [Mathematic-auxologic models and yield tables for forest stands]. Ceres Publishing House, Bucharest, $607 \mathrm{p}$.

Harmon ME, Sexton J (1996). Guidelines for measurements of woody detritus in forest ecosystems (Vol. 20). Seattle (WA): US LTER Network Office.

Harmon ME, Franklin JF, Swanson FJ, Sollins P, Gregory SV, Lattin JD, ... Cummins KW (1986). Ecology of coarse woody debris in temperate ecosystems. Advances in Ecological Research 15:133-302.

Harmon ME, Ferrell WK, Franklin JF (1990). Effects on carbon storage of conversion of old-growth forests to young forests. Science 247:699-702.

Harmon ME, Fasth B, Woodall CW, Sexton J (2013). Carbon concentration of standing and downed woody detritus: effects of tree taxa, decay class, position, and tissue type. Forest Ecology and Management 291:259-267.

Heilmann-Clausen J, Christensen M (2003). Fungal diversity on decaying beech logs-implications for sustainable forestry. Biodiversity and Conservation 12:953-973.

Hui GY, Gadow Kv (2002). Das Winkelmass - Theoretische Überlegungen zum optimalen Standardwinkel [The optimum standard angle of the Winkelmaß]. Allgemeine Forst - und Jagdzeitung 173:173-176.

Keller M (2011). Swiss National Forest Inventory. In: Keller M (Ed). Manual of the Field Survey 20042007. Swiss Federal Research Institute WSL, Birmensdorf, $\mathrm{CH}$. 
Korpel' S (1995). Die Urwälder der Westkarpaten [Old-growth Forests in the Western Carpathian Mountains]. Gustav Fischer,Stuttgart,DE.

LombardiF, CherubiniP, Lasserre B, Tognetti R, Marchetti M(2008). Tree rings used to assess time since death of deadwood of different decay classes in beech and silver fir forests in the central Apennines (Molise, Italy). Canadian Journal of Forest Research 38:821-833.

McLain DH (1974). Drawing contours from arbitrary data points. The Computer Journal 17:318-324.

Meyer P (1999). Tothholzuntersuchungen in nordwest-deutschen Naturwälder: Methodik und erste Ergebnisse [Dead wood research in forest reserves of Northwest-Germany: methodology and results]. Forstwissenschaftliches Centralblatt 118: 167-180.

Meyer P, Tabaku V, Lüpke Bv. (2003). Struktur albanischer RotbuchenUrwälder - Ableitungen für eine naturnahe Buchenwirtschaft [Structural Characteristics of Albanian Beech (Fagus sylvatica L.) Virgin Forests-Deductions for Semi-Natural Forestry]. Forstwissenschaftliches Centralblatt 122:47-58. P (1997). European woodpeckers and anthropogenic habitat change: a review. Vogelwelt 118:277-83.

Odor P, Standovar T (2001). Richness of bryophyte vegetation in a nearnatural and managed beech stands: the effects of management-induced differences in deadwood. Ecological Bulletin 49:219-230.

Odor P, Standovar T (2002). Substrate specificity and community structure of bryophyte vegetation in a near-natural montane beech forest. CommunityEcology 3:39-49.

Oheimb Gv, Westphal Ch, Härdtle W (2007). Diversity and spatiotemporal dynamics of dead wood in a temperate near-natural beech forest (Fagussylvatica). European Journal Forest Research 126:359-370.

Parish R, Antos JA, Fortin MJ (1999). Stand development in an old-growth subalpine forest in southern interior British Columbia. Canadian Journal of Forest Research 29:1347-1356.

Peterken GF (2001). Natural woodland: ecology and conservation in northern temperate regions, Reprinted. Cambridge Univ Press, New York.

Petritan AM, Nuske RS, Petritan IC, Tudose NC (2013). Gap disturbance patterns in an old-growth sessile oak (Quercus petraea L.) - European beech (Fagus sylvatica L.) forest remnant in the Carpathian Mountains, Romania. ForestEcology and Management 308:67-75.

Petritan IC, Marzano R, Petritan AM, Lingua E (2014). Overstory succession in a mixed Quercus petraea - Fagus sylvatica old growth forest revealed through the spatial pattern of competition and mortality. Forest Ecology and Management 326:9-17.
Petritan IC, Commarmot B, Hobi ML, Petritan AM, Bigler C, Abrudan IV, Riging A (2015). Structural patterns of beech and silver fir suggest stability and resilience of the virgin forest Sinca in the Southern Carpathians, Romania. Forest Ecology and Management 356:184-195.

Rahman MM, Frank G, Ruprecht H, Vacik H (2008). Structure of coarse woody debris in Lange-Leitn Natural Forest Reserve, Austria. Journal of ForestScience 54:161-169.

Rouvinen S, Kouki J (2002). Spatiotemporal availability of dead wood in protected old-growth forests: a case study from Boreal Forests in Eastern Finland. Scandinavian Journal of Forest Research 17:317-329.

Siitonen J (2001) Forest management, coarse woody debris and saproxylic organisms: Fennoscandian boreal forests as an example. Ecological Bulletins 49:11-41.

StatSoft Inc (2013). STATISTICA (Data Analysis Software System), version 12.http://www.statsoft.com

Stokland J, Siitonen J, Jonsson BG (2012). Biodiversity in dead wood. Cambridge University Press.

Tabaku V (2000). Struktur von Buchen-Urwäldern in Albanien im Vergleich mit deutschen Buchen-Naturwaldreservaten und Wirtschaftswäldern [Structure of Albanian virgin beech forests compared to German beech natural reserves and managed forests]. CuvillierVerlag, Göttingen.

Vacek S, Vacek Z, Bílek L, Hejcmanová P, Sticha V, Remes J (2015). The dynamics and structure of dead wood in natural spruce-beech forest stand-a 40 year case study in the Krkonose National Park. Dendrobiology 73:21-32.

Vandekerkhove K, de Keersmaeker L, Menke N, Meyer P, Verschelde P (2009). When nature takes over from man: dead wood accumulation in previously managed oak and beech woodlands on North-western and Central Europe. Forest Ecology and Management 258:425-435.

Veen P, Fanta J, Raev I, Biris IA, de Smidt J, Maes B (2010). Virgin forests in Romania and Bulgaria: results of two national inventory projects and their implications for protection. Biodiversity Conservation 19:18051819.

Vrška T, Hort L, Adam D, Odehnalová P, Horal D (2001). Virgin forest reserves in the Czech Republic and their developmental dynamics. 1 The Bohemian-Moravian Upland (Polom, Žákova hora). Academia, Praha.

Wirth C, Czimczik CI, SchulzeED (2002). Beyond annual budgets: carbon flux at different temporal scales in fire-prone Siberian Scots pine forests. Tellus B: Chemical and Physical Meteorology 54:611-630. 